\title{
JIMMBA
}

Jurnal Ilmiah Mahasiswa Manajemen, Bisnis dan Akuntansi

Homepage: $h$ ttp://journal.stieputrabangsa.ac.id/index.php/jimmba/index

\section{Analisis Kinerja Portofolio Saham dengan Metode Sharpe, Treynor, dan Jensen}

(Saham IDX30 Tahun 2015 sampai 2019)

Siti Nurlaeli', Dwi Artati ${ }^{2}$

1,2Sekolah Tinggi Ilmu Ekonomi Putra Bangsa

Email: laelazixty96@gmail.com¹, dwiartati81@yahoo.co.id²

\section{ARTICLE INFO}

Article History:

Received: October27th 2020

Accepted: November $1^{\text {st }} 2020$

Published: December $1^{\text {st }} 2020$

Keywords:

Indeks Sharpe, Treynor, Jensen, Kinerja Portofolio Optimal, Kruskal Wallis

\begin{abstract}
Penelitian ini bertujuan untuk mengetahui ada atau tidak ada perbedaan antara metode Sharpe, Treynor, dan Jensen dalam mengukur portofolio IDX30 yang optimal. Penelitian ini menggunakan uji beda One Way of Variance by Rank Kruskal Wallis. Dalam penelitian ini nilai Sharpe, Treynor, dan Jensen distandarkan melalui transformasi Zscore (standardized) dilanjutkan uji beda Mean Rank antar treatment untuk menentukan kinerja indeks mana yang paling konsisten. Hasil pengujian menggunakan uji Kruskal Wallis diperoleh x2 $=0,598$, dengan probabilitas sebesar 0,742. Diketahui bahwa probabilitas pengujian $\geq$ 0,05 . Hasil ini menunjukkan bahwa tidak ada perbedaan yang signifikan antara pengujian dengan metode Sharpe, Treynor, dan Jensen. Dengan demikian, hipotesis nihil HO dalam penelitian ini diterima. Hasil uji antar treatment selisih ketiga mean rank, menunjukkan tidak ada perbedaan yang bermakna antara masingmasing treatment karena selisihnya tidak begitu jauh. Metode Sharpe memiliki selisih mean rank yang paling rendah terhadap Treynor maupun Jensen, artinya Sharpe paling konsisten terhadap ketidakbedaan.
\end{abstract}

\section{Pendahuluan}

Investasi merupakan penempatan sejumlah dana pada saat ini dengan harapan untuk memperoleh keuntungan di masa mendatang. Investasi terdiri dari financial assets (pasar uang dan pasar modal) dan real assets. Dalam berinvestasi banyak hal yang menjadi pertimbangan untuk memilih jenis investasi mana yang sebaiknya dipilih. Proses investasi terdiri dari tahapan penentuan tujuan investasi, analisis fundamental dan teknikal, pembentukan portofolio, evaluasi kinerja portofolio, dan revisi kinerja portofolio. Tujuan investasi adalah guna memaksimalkan return dengan risiko seminimal mungkin. Return merupakan salah satu faktor yang memotivasi investor dalam berinvestasi sekaligus sebagai imbalan atas keberaniannya dalam menanggung risiko investasi yang dilakukan (Tandelilin, 2010:102). Kegiatan analisis fundamental biasa dilakukan dengan memperhatikan latar belakang 
manajemen dan struktur manajerial perusahaan. Di sisi lain, analisis teknikal lebih memperhatikan historis pergerakan harga saham pada periode sebelumnya untuk meramalkan pergerakan harga saham dan perolehan keuntungan di masa mendatang.

Pembentukan portofolio (diversifikasi) dilakukan dengan melakukan pemilihan kombinasi sejumlah risiko investasinya semakin minimal tanpa mengurangi return yang diharapkan. Pengukuran kinerja portofolio dilakukan guna mengetahui apakah sasaran investor dapat tercapai atau tidak. Menurut Hartono (2010: 637) pencapaian sasaran investor perlu diukur setiap saat melalui perbandingan kinerja portofolio dengan benchmark sasaran investor. Kinerja portofolio dapat dihitung berdasarkan return portofolionya saja, namun karena adanya tukaran (trade-off) antara return dan risiko, maka faktor risiko pun perlu dipertimbangkan oleh investor. Pengukuran yang melibatkan faktor return dan risiko disebut return sesuaian risiko (risk-adjusted return).

Hubungan positif antara return dan risiko dalam berinvestasi dikenal dengan high risk-high return, yang artinya semakin besar risiko yang harus ditanggung, semakin besar pula return yang dihasilkan. Realitanya return yang tinggi belum tentu merupakan hasil investasi yang baik, karena return yang rendah juga dapat memberikan hasil investasi yang baik jika return yang rendah ini disebabkan oleh risiko yang rendah pula. Oleh karena itu, return yang dihitung perlu disesuaikan dengan risiko yang harus ditanggungnya. Ada beberapa metode perhitungan return sesuaian risiko (risk-adjusted return) seperti reward to variability (Sharpe Measure), reward to volatility (Treynor Measure), reward to market risk, reward to diversification, Jensen's alpha, $M^{2}$, dan rasio informasi (information ratio) (Hartono, 2010: 640).

Hartono (2010: 285) menyatakan bahwa dalam membentuk suatu portofolio akan timbul masalah, yaitu banyaknya kemungkinan portofolio yang dapat dibentuk dari kombinasi aktiva berisiko yang tersedia di pasar. Jika terdapat kemungkinan portofolio yang jumlahnya tidak terbatas, maka akan timbul pertanyaan portofolio mana yang akan dipilih oleh investor. Jika investor bersikap rasional, maka mereka akan memilih portofolio saham yang optimal. Analisis kinerja saham yang optimal menggunakan metode Sharpe, Treynor, dan Jensen dapat digunakan dalam pemilihan investasi dengan melihat kondisi pasar yang sedang berlangsung. Ketiga metode tersebut mendasarkan analisisnya pada return masa lalu untuk memprediksi return dan risiko di masa datang.

Metode Sharpe menekankan pada risiko total (deviasi standar), Treynor menganggap fluktuasi pasar sangat berperan dalam mempengaruhi return (beta), sedangkan Jensen sendiri menekankan pada alpha. Ketiga metode tersebut mempunyai karakteristik tersendiri dalam mengukur risiko investasi. Pengukuran kinerja portofolio dengan metode Sharpe, Treynor, dan Jensen memiliki karakteristik angka indeks yang berbeda satu sama lain, sehingga tidak dapat dibandingkan satu sama lainnya secara langsung, maka diperlukan standarisasi ukuran kinerja portofolio investasi (Hartono, 2010: 285).

Portofolio merupakan investasi dalam berbagai surat berharga seperti saham, obligasi, pasar uang, dan produk derivatif. Dalam penelitian ini, penulis berfokus pada analisis kinerja portofolio investasi saham-saham yang tergabung dalam IDX30. Berdasarkan data idx.co.id pada tahun 2019, ada 24 indeks yang ada di Bursa Efek Indonesia yaitu LQ45, SRI-KEHATI, Kompas100, IDX30, IDXBUMN20, IDX80, PEFINDO, IDXV30, dan sebagainya. 
IDX30 merupakan salah satu indeks di Bursa Efek Indonesia yang berisi 30 perusahaan dengan tingkat liquiditas tinggi sekaligus hasil dari penyortiran saham LQ45. Kriteria kuantitatif yang menjadi pertimbangan dalam pemilihan saham IDX30 adalah aktivitas transaksi yang meliputi nilai transaksi, frekuensi transaksi, hari transaksi, serta kapitalisasi pasar (Hartono, 2015: 163).

Sejak diluncurkan pada tahun 2012, IDX30 telah menarik minat banyak manajer investasi maupun investor dalam menyusun portofolio investasinya, hal ini dapat dilihat dalam ilustrasi grafik I-1di bawah ini.

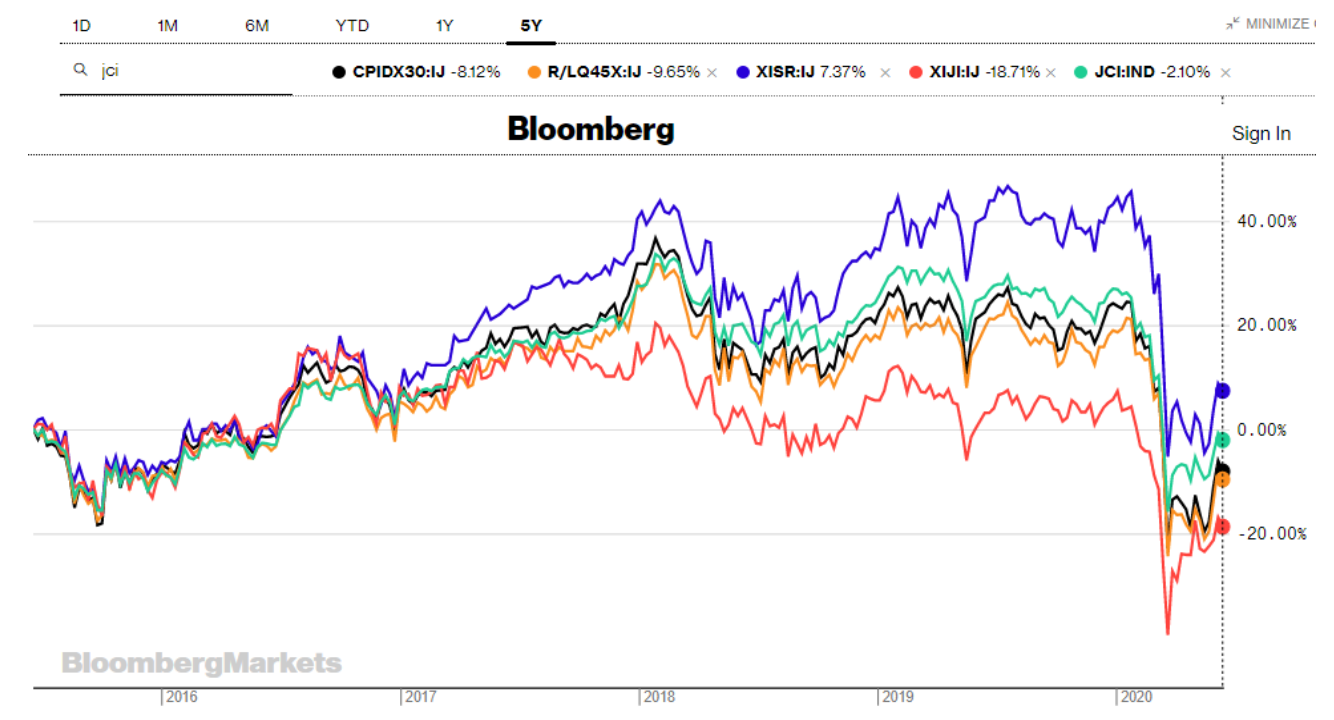

Grafik 1. Ilustrasi Perbandingan Pergerakan Pasar Indeks

Sumber: https://www.bloomberg.com/quote/CPIDX30:IJ (2020)

Berdasarkan ilustrasi grafik 1 di atas, pergerakan harga saham dalam IDX30 (CPIDX30:IJ) yang berwarna hitam sering mendekati IHSG (JCI:IND) yang berwarna hijau. Indeks SRIKEHATI (XISR:IJ) yang diilustrasikan dengan garis berwarna biru memang sering berada di atas IHSG (outperform) karena komposisi anggota indeksnya 55,1\% merupakan sektor keuangan, sementara persentase sektor keuangan dalam IDX30 sebesar 45,3\%. Dalam berinvestasi, baik manajer investasi maupun investor seringkali khawatir apakah portofolio saham yang mereka miliki sudah cukup baik dalam menggambarkan return dan risiko instrumen investasinya atau belum. Hal ini bisa diantisipasi dengan melakukan pengukuran kinerja portofolio untuk menemukan portofolio yang optimal dalam berinvestasi. Portofolio yang optimal dapat tercapai setelah melalui tahapan penentuan tujuan investasi, penentuan ekspektasi pasar, menyusun portofolio, hingga evaluasi kinerja portofolio untuk menemukan manakah portofolio yang kinerjanya optimal. 
Tabel 1. Daftar dan Performa Ringkas Indeks BEI

\begin{tabular}{|c|c|c|c|c|c|c|}
\hline \multirow[b]{2}{*}{ No } & \multirow[b]{2}{*}{ Nama Indeks } & \multirow{2}{*}{$\begin{array}{l}\text { Jumlah } \\
\text { Konstitue } \\
\text { n }\end{array}$} & \multirow{2}{*}{$\begin{array}{l}\text { Return } \\
5 \mathrm{Y}\end{array}$} & \multicolumn{2}{|c|}{ Risk (3Y)* } & \multirow{2}{*}{$\begin{array}{l}\text { Jumlah } \\
\text { Produk } \\
\text { Berbasis } \\
\text { Indeks }\end{array}$} \\
\hline & & & & Beta & Dev.Std & \\
\hline 1 & IHSG & 671 & $20.5 \%$ & 1 & $2.72 \%$ & - \\
\hline 2 & IDX80 & 80 & $11.0 \%$ & 1,28 & $3.57 \%$ & - \\
\hline 3 & LQ45 & 45 & $12.9 \%$ & 1,26 & $3.52 \%$ & 8 \\
\hline 4 & IDX30 & 30 & $20.0 \%$ & 1,28 & $3.60 \%$ & 20 \\
\hline 5 & IDX Value30 & 30 & $25.6 \%$ & 1,38 & $4.40 \%$ & 2 \\
\hline 6 & IDX Growth30 & 30 & $20.2 \%$ & 1,31 & $3.79 \%$ & - \\
\hline 7 & IDX High Dividend 20 & 20 & $15.6 \%$ & 1,31 & $3.73 \%$ & 1 \\
\hline 8 & IDX BUMN20 & 20 & $9.2 \%$ & 1,4 & $4.24 \%$ & - \\
\hline 9 & $\begin{array}{l}\text { Indeks Saham Syariah Indonesia } \\
\text { (ISSI) }\end{array}$ & 429 & $11.3 \%$ & 0,95 & $2.73 \%$ & - \\
\hline 10 & Jakarta Islamic Index 70 (JII) & 70 & $0.5 \%$ & 1,17 & $3.38 \%$ & - \\
\hline
\end{tabular}

Sumber: IDX Stock Index Handbook v1.1 (2019)

Berdasarkan Tabel 1, IDX30 paling banyak digunakan sebagai acuan produk berbasis indeks dalam indeks ETF dan indeks reksadana. Hal ini menggambarkan bahwa portofolio investasi saham para manajer investasi banyak yang menggunakan IDX30.

Dengan melihat latar belakang masalah dan karakteristik yang berbeda dari indeks Sharpe, Treynor, dan Jensen dalam penentuan risiko dan return investasi, maka investor seringkali mengalami kesulitan dalam mengevaluasi kinerja portofolionya, maka penelitian ini perlu dilakukan guna evaluasi lebih lanjut mengenai kinerja dari portofolio saham-saham IDX30 dengan menggunakan metode Sharpe, Treynor, dan Jensen yang dirumuskan dalam pertanyaan apakah ada perbedaan antara penilaian kinerja portofolio dengan menggunakan metode Sharpe, Treynor, dan Jensen serta apa saja saham yang layak untuk diinvestasikan berdasarkan metode Sharpe, Treynor, dan Jensen.

Penelitian ini bertujuan untuk mengukur perbandingan peringkat kinerja dari metode Sharpe, Treynor, dan Jensen dari portofolio saham-saham IDX30, apakah hasil yang didapat sama atau ada perbedaan antara ketiga metode tersebut. Penelitian ini juga bertujuan untuk mengetahui saham-saham IDX30 yang layak untuk diinvestasikan berdasarkan metode Sharpe, Treynor, dan Jensen.

\section{Kajian Teori dan Telaah Literatur}

\section{Teori Portofolio}

Teori portofolio diperkenalkan oleh Harry M. Markowitz pada tahun 1952. Teori ini dilatarbelakangi oleh keinginan investor yang ingin meminimalkan risiko investasinya. Teori portofolio menghendaki penanaman saham di beberapa emiten yang berbeda untuk menghindari kerugian (diversifikasi portofolio). Teori portofolio membahas bagaimana cara 
membentuk portofolio yang dapat memberikan keuntungan optimal dari sekian banyak aset yang harus dipilih pada tingkat risiko yang bersedia ditanggung (Maf'ula, dkk, 2018: 19).

\section{Capital Asset Pricing Model (CAPM)}

Kemampuan untuk mengestimasikan return saham merupakan hal yang sangat penting dan diperlukan oleh investor. Untuk dapat mengestimasi return suatu saham dengan baik dan mudah, diperlukan suatu metode estimasi yaitu dengan menggunakan Capital Asset Pricing Model (CAPM), (Hartono, 2012:487).

\section{Investasi}

Investasi adalah kegiatan menunda konsumsi sekarang untuk dimasukkan ke aktiva produktif selama periode waktu yang tertentu untuk meningkatkan utiliti total (Hartono, 2010: 5). Investasi merupakan penempatan sejumlah dana pada saat ini dengan harapan untuk memperoleh keuntungan di masa mendatang yang terdiri dari financial assets (pasar uang dan pasar modal) dan real assets. Investasi pada financial assets dilakukan di pasar uang, misalnya deposito, commercial paper, surat berharga pasar uang, dan lainnya. Investasi pada financial asset di pasar modal, misalnya berupa saham, obligasi, waran, opsi, reksadana, dan lainnya. Investasi pada real assets diwujudkan dalam pembelian aset produktif, pendirian pabrik, pembukaan pertambangan, perkebunan, dan lainnya (Halim, 2015: 13).

\section{Portofolio Efisien}

Portofolio efisien merupakan portofolio yang memberikan return ekspektasi terbesar dengan tingkat risiko yang sudah pasti atau portofolio yang memberikan risiko terkecil dengan tingkat return ekspektasi yang sudah pasti. Portofolio dapat dikatakan efisien apabila memiliki tingkat risiko yang sama dan juga mampu memberikan tingkat keuntungan yang lebih tinggi, atau dengan kata lain mampu menghasilkan tingkat keuntungan yang sama, tetapi dengan risiko yang lebih rendah. Bagi investor, efficient market hypotesis (EMH) dan risk and return tradeoff memberikan strategi terkait bagimana memilih tingkat risiko yang aman, menciptakan diversifikasi portofolio yang terseleksi dengan baik, dan meminimalisir biaya transaksi dengan buy and hold strategy (Wiyono \& Kusuma, 2017: 22).

\section{Portofolio Optimal}

Portofolio optimal merupakan portofolio pilihan dari berbagai sekuritas dari portofolio efisien. Portofolio optimal ini dapat ditentukan dengan memilih tingkat return ekpektasi tertentu dan kemudian meminimumkan risikonya, atau menentukan tingkat risiko yang tertentu dan kemudian memaksimumkan return ekspektasinya. Investor yang rasional akan memilih portofolio optimal karena merupakan portofolio yang dibentuk dengan mengoptimalkan satu dari dua dimensi, yaitu return ekspektasi atau risiko portofolio. Salah satu konsep pengukuran kinerja portofolio yang banyak digunakan adalah hasil kombinasi return portofolio dibagi dengan risiko portofolionya. Oleh karena itu, secara khusus portofolio optimal adalah portofolio yang memberikan hasil kombinasi return tertinggi dengan risiko terendah. Portofolio optimal juga dapat berupa portofolio dengan risiko terkecil. Terdapat empat tahapan proses portofolio menurut Halim (2005), yaitu: tahap penentuan tujuan investasi, ekspektasi pasar, membangun portofolio, dan evaluasi kinerja. 


\section{Return Portofolio}

Menurut Tandelilin (2010: 102) return merupakan pengembalian atas keberanian investor untuk menanggung risiko atas investasi yang dilakukan. Return saham terdiri dari yield dan capital gain (loss). Ada 2 jenis return, yaitu: return realisasi merupakan return yang telah terjadi. Return ini dihitung berdasarkan data historis. Return realisasi penting karena digunakan sebagai salah satu pengukur kinerja dari sebuah perusahaan. Return historis juga berguna sebagai dasar penentuan return ekspektasi dan risiko di masa mendatang. Return yang kedua adalah return ekspektasi yang digunakan untuk pengambilan keputusan investasi. Return ini penting dibandingkan dengan return historis karena return ekspektasi merupakan return yang diharapkan dari investasi yang dilakukan (Hartono, 2012: 283)

\section{Risiko Portofolio}

Konsep risiko portofolio pertama kali diperkenalkan oleh Harry M. Markowitz di tahun 1950 yang menyatakan bahwa bahwa secara umum risiko mungkin dapat dikurangi dengan menggabungkan beberapa sekuritas tunggal ke dalam bentuk portofolio (Hartono, 2012: 255). Risiko merupakan kemungkinan terjadinya perbedaan antara return realisasi dengan return ekspektasi. Semakin besar kemungkinan perbedannya, berarti semakin besar risiko investasi tersebut. Ada beberapa sumber yang dapat mempengaruhi besarnya risiko suatu investasi, yaitu: risiko suku bunga, risiko pasar, risiko inflasi, risiko bisnis, risiko finansial, risiko likuiditas, risiko nilai tukar mata uang, dan risiko negara (Tandelilin, 2010:103).

Menurut Samsul (2015: 310) untuk mengurangi risiko investasi, investor harus mengetahui jenis risiko investasi. Jenis risiko dikelompokkan menjadi dua, yaitu risiko sistematis (systematic risk/undifersifiable risk), risiko tidak sistematis (unsystematic risk/specific risk/difersifiable risk/unique risk), dan risiko total (total risk).

Apabila risiko sistematis terjadi, maka semua jenis saham akan terkena dampaknya sehingga tindakan diversifikasi tidak dapat mengurangi kerugian. Contoh risiko sistematis yaitu: inflasi, tingkat bunga, kebijakan fiskal, pertumbuhan ekonomi, kurs valuta asing, dan siklus ekonomi. Risiko tidak sistematis merupakan risiko yang masih dapat didiversifikasikan, karena hanya berdampak pada suatu saham atau sektor tertentu saja (Samsul, 2015: 310).

Risiko total suatu portofolio disebut deviasi standar portofolio $\left(\sigma_{\mathrm{p}}\right)$ yang merupakan gabungan dari risiko sistematis dan risiko tidak sistematis. Pada akhirnya suatu portofolio tidak mungkin menghasilkan return yang maksimal, namun dapat diupayakan untuk menghasilkan return yang optimal dengan risiko yang lebih kecil (Tandelilin, 2010:104)

\section{Penilaian Evaluasi Kinerja Portofolio}

Menurut Tandelilin (2010: 488) penilaian evaluasi kinerja portofolio dilakukan untuk mengetahui dan menganalisa apakah portofolio yang dibentuk dapat meningkatkan kemungkinan tercapainya tujuan investasi dari tingkat pengembalian serta risikonya. Dengan kata lain apakah return portofolio yang telah dibentuk, sudah mampu mengkompensasi tingkat risiko yang harus ditanggung investor. 
Perhitungan return sesuaian risiko (risk adjusted return) seperti reward to variability, reward to volatility, reward to market risk, reward to diversification, Jensen's alpha, $M^{2}$, dan ratio information. Menurut Samsul (2015: 428) ada beberapa istilah yang dapat digunakan untuk menyebutkan maksud yang sama dalam mengukur kinerja portofolio, yaitu indeks, ukuran, dan metode. Dalam penelitian ini metode yang digunakan adalah metode Sharpe, Treynor, dan Jensen.

\section{Metode Sharpe}

Indeks Sharpe dikembangkan oleh William F. Sharpe pada tahun 1966. Kinerja portofolio Sharpe (reward to variability/RVAR) dihitung dengan membagi return lebih (excess return) dengan variabilitas (variability) return portofolio (Hartono, 2017: 729). Sharpe merupakan penilaian dengan cara membandingkan antara premi risiko portofolio (selisih rata-rata tingkat keuntungan portofolio dengan rata-rata suku bunga bebas risiko) dengan risiko portofolio yang dinyatakan dengan standar deviasi (risiko total). Metode Sharpe biasa digunakan untuk investor yang menggunakan dananya hanya atau sebagian besar pada portofolio tersebut, sehingga risiko portofolio dinyatakan dengan standar deviasi (Halim, 2015).

Untuk menghitung indeks Sharpe dapat digunakan persamaan berikut (Tandelilin, 2010: 494):

$$
\mathrm{Sp}=\frac{\overline{\mathrm{Rp}}-\overline{\mathrm{Rf}}}{\sigma \mathrm{TR}}
$$

Keterangan:

Sp : indeks Sharpe portofolio

$\overline{\mathrm{R}_{\mathrm{p}}} \quad$ : rata-rata return portofolio $\mathrm{p}$ selama periode pengamatan

$\overline{\mathrm{Rf}} \quad$ : rata-rata tingkat return bebas risiko selama periode pengamatan

$\overline{\mathrm{OTR}_{\mathrm{TR}}} \quad$ : standar deviasi return portofolio $\mathrm{p}$ selama periode pengamatan

Premi risiko portofolio, Rp-Rf merupakan kompensasi untuk memikul risiko. Deviasi standar return portofolio merupakan pengukur risiko total suatu sekuritas atau portofolio. Menurut Tandelilin (2010: 494) indeks Sharpe dapat digunakan untuk membuat peringkat dari beberapa portofolio berdasarkan kinerjanya. Semakin tinggi indeks Sharpe suatu portofolio dibanding portofolio lainnya, maka semakin baik kinerja portofolio tersebut.

\section{Metode Treynor}

Indeks Treynor portofolio yang dikembangkan oleh Jack L. Treynor pada tahun 1966 merupakan ukuran kinerja yang disebut juga reward to volatility ratio (RVOL). Perhitungan indeks Treynor dapat dihitung menggunakan persamaan berikut (Hartono, 2017: 733):

$$
\mathrm{RVOL}=\frac{\overline{\mathrm{TRp}}-\overline{\mathrm{RBR}}}{\beta \mathrm{p}}
$$


Keterangan:

RVOL : reward to volatility atau pengukur Treynor

$\overline{\mathrm{TR}_{\mathrm{p}}} \quad$ : rata-rata return total portofolio periode tertentu

$\overline{\mathrm{RB}_{R}} \quad$ : rata-rata aktiva bebas risiko periode tertentu

$\quad \quad \quad \quad$ : volatilitas menggunakan beta portofolio periode tertentu

$\overline{\mathrm{TR}_{\mathrm{p}}}-\overline{\mathrm{RB}_{R}} \quad$ :return lebih (excess return) portofolio

Nilai RVOL menunjukkan kinerja portofolio, yang mana semakin besar nilai RVOL maka semakin baik kinerja portofolionya. Treynor berargumentasi bahwa portofolio yang dibentuk seharusnya adalah portofolio optimal, maka risiko unik (unsystematic risk) dapat diabaikan dan yang masih tertinggal adalah risiko sistematis yang diukur dengan $\beta$ (Hartono, 2017: 733). Hal ini dilakukan karena Treynor berasumsi bahwa portofolio sudah terdiversifikasi dengan baik sehingga risiko yang dianggap relevan adalah risiko sistematis (Tandelilin, 2010: 497).

\section{Metode Jensen}

Indeks Jensen diperkenalkan oleh Michael C. Jensen pada tahun 1968 yang merupakan pengembangan dari CAPM. Karena digunakan untuk mengukur kinerja historis portofolio, maka nilai ekspektasian di persamaan CAPM dan nilai aktiva bebas risikonya menggunakan rata-rata historisnya (Hartono, 2017: 742). Pengukur Jensen (Jensen's Alpha) merupakan selisih antara return rata-rata portofolio dengan nilai menurut CAPM. Perhitungannya dapat dilakukan menggunakan persamaan berikut (Hartono, 2017: 743):

$$
\begin{gathered}
\alpha \mathrm{p}=\overline{\mathrm{TR}}_{\mathrm{p}}-\overline{\mathrm{R}_{\mathrm{BR}}}-\beta \mathrm{p}\left(\mathrm{R}_{\mathrm{M}}-\mathrm{R}_{\mathrm{BR}}\right) \\
\overline{\mathrm{TR}}_{p}=\overline{R_{B R}}+\beta \mathrm{p}\left(R_{M}-R_{B R}\right)
\end{gathered}
$$

Keterangan:

$\begin{array}{ll}\text { ap } & \text { : Jensen's Alpha } \\ \overline{\mathrm{TR}}_{p} & : \text { rata-rata return portofolio periode tertentu } \\ \overline{R_{B R}} & : \text { rata-rata return aktiva bebas risiko periode tertentu } \\ \mathrm{R}_{\mathrm{M}} & : \text { rata-rata return pasar periode tertentu } \\ \mathrm{R}_{\mathrm{M}}-\mathrm{R}_{\mathrm{BR}} & : \text { rata-rata premium risiko pasar }\end{array}$

Indeks Jensen yang bernilai positif berarti portofolio memberikan return lebih besar dari return harapannya, sehingga mempunyai return yang relatif tinggi untuk tingkat risiko sistematisnya, begitu juga sebaliknya (Tandelilin, 2010: 500). 


\section{Kerangka Teoritis}

Penelitian ini dilakukan dengan cara memilih saham IDX30 yang memenuhi kriteria sampel, kemudian mencari return saham $(R p)$ serta return market. Hasil dari perbandingan return portofolio $(R p)$ dengan return market $(R m)$ dapat digunakan untuk menilai kinerja portofolionya, apakah outperform atau justru underperform untuk mengetahui mana saja saham yang layak untu dipilih. Hal ini selaras dengan penelitian Manurung (2019) yang menilai kelayakan saham berdasarkan outperform dan underperform $\mathrm{Rp}$ dengan $\mathrm{Rm}$. Tahapan setelah menemukan nilai return dilanjutkan dengan menghitung rata-rata aritmatik, rata-rata geometrik, standar deviasi, dan beta untuk menghitung Sharpe, Treynor, serta Jensen.

Langkah selanjutnya adalah menghitung nilai Sharpe, Treynor, dan Jensen masing-masing perusahaan untuk menemukan perusahaan mana yang nilai Sharpe, Treynor, dan Jensen-nya paling baik berdasarkan nilai Sharpe, Treynor, dan Jensen sebelum dibuat peringkat. Tahap terakhir adalah menguji ada tidaknya perbedaan antara kinerja portofolio saham metode Sharpe, Treynor, dan Jensen menggunakan uji Kruskal Wallis dan uji treatment setelah data ditransformasi ke dalam Zscore. Tahapan ini selaras dengan penelitian Sulistyorini (2009) yang melakukan uji beda terhadap indeks Sharpe, Treynor, dan Jensen pada saham LQ45 seperti yang tercantum dalam kerangka penelitian berikut.

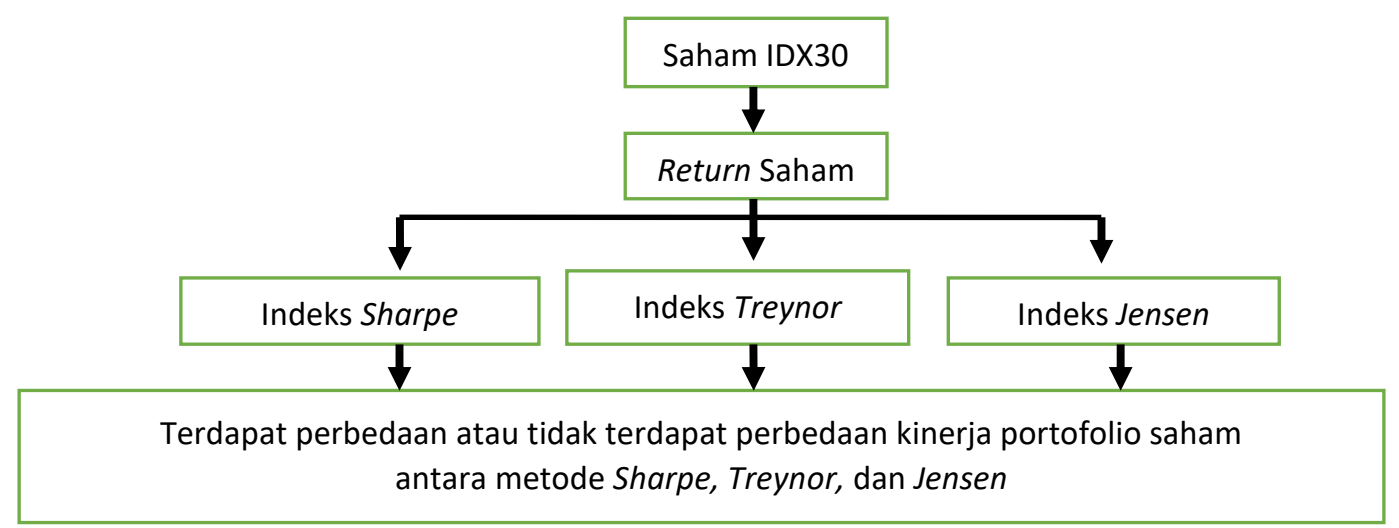

Bagan 1. Kerangka Penelitian

\section{Hipotesis}

Adapun hipotesis yang diajukan dalam penelitian ini sebagaimana penelitian Sulistyorini (2009) adalah sebagai berikut:

$\mathbf{H}_{0} \quad$ : Tidak terdapat perbedaan kinerja portofolio yang signifikan antara saham IDX30 yang dievaluasi dengan menggunakan metode Sharpe, Treynor, dan Jensen.

$\mathbf{H}_{\mathbf{1}} \quad$ : Terdapat perbedaan kinerja portofolio saham yang signifikan antara saham IDX30 yang dievaluasi dengan menggunakan metode Sharpe, Treynor, dan Jensen. 


\section{Metode Penelitian}

Penelitian ini merupakan penelitian kuantitatif dengan menggunakan uji beda. Uji ini dilakukan untuk mengkomparasikan kinerja portofolio saham IDX30 yang diukur menggunakan metode Sharpe, Treynor, dan Jensen. Objek dalam penelitian ini adalah indeks Sharpe, Treynor, dan Jensen. Subjek dalam penelitian ini adalah perusahaan yang terdaftar di IDX30 pada periode 2015-2019.

Data-data yang dikumpulkan dalam penelitian ini adalah data sekunder, time series, dan cross section yang dilakukan dengan observasi atau pengamatan dari saham-saham IDX30 di Bursa Efek Indonesia (BEI) untuk menemukan daftar saham anggota IDX30, Yahoo Finance untuk menemukan closing price saham dan IHSG, dan Badan Pusat Statistik untuk menemukan tingkat suku bunga SBI. Data yang diperoleh terlebih dahulu diolah menggunakan Office Excel untuk smoothing data dan menemukan nilai indeks Sharpe, Treynor, serta Jensen.

Populasi dalam penelitian ini adalah saham-saham yang terdaftar di IDX30 pada tahun 2015 hingga 2019. Pengambilan sampel dilakukan dengan purposive sampling dengan kriteria tertentu, yaitu saham-saham yang masuk dalam IDX30 selama 5 tahun pada periode pengamatan berturut-turut antara tahun 2015-2019 dan tidak melakukan stock split, dikarenakan akan menyebabkan bias dalam perhitungan return saham.

Berdasarkan kriteria puposive sampling perusahaan di IDX30 yang menjadi sampel pada periode 2015-2019 dalam periode tahunan, maka ada 14 perusahaan terpilih yaitu ADRO, ASII, BBCA, BBNI, GGRM, INDF, INTP, KLBF, LPPF, PGAS, SMGR, TLKM, UNTR, dan UNVR. Dari 14 perusahaan yang terpilih kemudian dikalikan dengan periode pengamatan selama 5 tahun sehingga jumlah seluruh data $(\mathrm{N})$ dalam penelitian ini adalah: $14 \times 5=70$ sampel.

\section{Perbandingan Kinerja Portofolio Melalui Uji Statistik}

Uji Kruskal Wallis digunakan untuk menentukan adakah perbedaan signifikan secara statistik antara dua atau lebih kelompok variabel independen pada variabel dependen yang berskala data numerik (interval/ rasio) dan skala ordinal. Uji ini identik dengan Uji One Way Anova pada pengujian parametris, sehingga uji ini merupakan alternatif bagi uji One Way Anova apabila tidak memenuhi asumsi, misalnya asumsi normalitas.

Mengingat ukuran kinerja untuk masing-masing metode Sharpe, Treynor, dan Jensen memiliki karakteristik yang berbeda, dalam hal ini masing-masing metode tidak memiliki batas maksimal kinerja yang sama, maka perlu dilakukan transformasi untuk menstandarkan ukuran kinerja tersebut yaitu dengan menggunakan transformasi Z-score (standard-ized). Z-score adalah cara mengkonversikan nilai data ke dalam skor standardized yang memiliki nilai means (rata-rata) sama dengan nol dan standar deviasinya sama dengan satu (Sulistyorini, 2009).

Setelah semua data dalam bentuk Z-score maka data tersebut dapat dilakukan uji beda menggunakan One Way of Variance by Rank dengan Kruskal-Wallis. Pengujian ini dilakukan untuk menghindari adanya kesamaan rata-rata (mean) dan standar deviasi akibat transformasi Z-Score jika menggunakan pengujian Anova satu arah. Menurut Supranto (2009: 312) uji Kruskal 
Wallis sebenarnya sama dengan uji F dalam ANOVA (Analysis of Varians) satu arah, hanya saja datanya berupa peringkat (peringkat). Jika data asli masih berupa interval atau rasio, harus diubah terlebih dahulu menjadi peringkat (peringkat atau ordinal). Ada atau tidaknya perbedaan dalam pengujian akan ditunjukkan dengan hasil probabilitas pengujian. Keputusan pengujian dalam penelitian ini sebagaimana keputusan dalam Sulistyorini (2009), yaitu jika probabilitas pengujian $\leq 0,05$ maka ketiga metode pengukuran kinerja portofolio adalah berbeda. Jika probabilitas pengujian $\geq 0,05$ maka ketiga metode pengukuran kinerja portofolio adalah tidak memiliki perbedaan yang signifikan.

Tahap selanjutnya setelah uji Kruskal Wallis adalah uji perbedaan Mean Rank antar treatment (perlakuan) pengukuran kinerja portofolio untuk menentukan metode kinerja mana yang paling konsisten. Yang diharapkan dari hasil pengujian adalah tidak adanya perbedaan dari hasil pengujian. Pengujian antar treatment yang memiliki nilai paling tidak berbeda merupakan bentuk metode pengukuran kinerja portofolio yang paling konsisten (Sulistyorini, 2009).

\section{Hasil dan Pembahasan}

\section{Pengukuran Kinerja Portofolio}

Pengukuran kinerja portofolio dapat dilakukan dengan melihat nilai rata-rata return portofolio $\mathrm{p}(R p)$ yang dibandingkan dengan nilai return IHSG $(R m)$ dan return SBI $(R f)$. Kinerja portofolio dianggap outperform ketika nilai $R p$ lebih besar dari nilai $R m$. Sebaliknya, kinerja portofolio dianggap underperform ketika nilai $R p$ lebih kecil dari $R m$ dan $R f$. Dalam penelitian ini kinerja portofolio dari saham-saham IDX30 berada dalam kondisi outperform, karena nilai $R p>R m$. Hal ini menunjukkan bahwa rata-rata return dari portofolio saham-saham IDX30 sudah cukup bagus dan berada di atas nilai return rata-rata IHSG.

\section{Analisis Kinerja Portofolio Saham dengan Metode Sharpe}

Pengukuran menggunakan metode Sharpe (Reward to Variability Ratio) menekankan pada risiko total melalui deviasi standar. Deviasi standar menunjukkan besar kecilnya perubahan return suatu saham terhadap return rata-rata saham yang bersangkutan. Untuk memprediksi kinerja portofolio di masa mendatang dapat digunakan data masa lalu. Return rata-rata masa lalu dianggap sebagai return prediksi masa yang akan datang dan deviasi standar return masa lalu dianggap sebagai prediksi risiko masa yang akan datang.

Dalam menganalisis kinerja keuangan menggunakan metode Sharpe diperlukan data berupa average return portofolio, deviasi standar, dan risk free rate (tingkat suku bunga). Hasil dari perhitungan kinerja portofolio saham dari ke-14 kelompok saham IDX30 dengan metode Sharpe periode 2015 hingga 2019 dapat dilihat dalam tabel 2: 
Tabel 2. Kinerja Portofolio Metode Sharpe

\begin{tabular}{llllll}
\hline Emiten & $\mathbf{2 0 1 5}$ & $\mathbf{2 0 1 6}$ & $\mathbf{2 0 1 7}$ & $\mathbf{2 0 1 8}$ & $\mathbf{2 0 1 9}$ \\
\hline ADRO & $-0,45853$ & 0,13541 & $-0,15430$ & $-0,17885$ & $-0,08319$ \\
ASII & $-0,29108$ & $-0,14541$ & $-0,30756$ & $-0,34760$ & $-0,33051$ \\
BBCA & $-0,31970$ & $-0,11374$ & $-0,00742$ & $-0,23330$ & $-0,29160$ \\
BBNI & $-0,22266$ & $-0,22785$ & 0,02630 & $-0,19450$ & $-0,27739$ \\
GGRM & $-0,27346$ & $-0,26932$ & $-0,09441$ & $-0,23084$ & $-0,32094$ \\
INDF & $-0,42361$ & $-0,06641$ & $-0,34095$ & $-0,24616$ & $-0,22717$ \\
INTP & $-0,22557$ & $-0,46671$ & $-0,02849$ & $-0,11853$ & $-0,20791$ \\
KLBF & $-0,46584$ & $-0,19592$ & $-0,26102$ & $-0,27659$ & $-0,22507$ \\
LPPF & $-0,20965$ & $-0,23621$ & $-0,19825$ & $-0,23146$ & $-0,12291$ \\
PGAS & $-0,28522$ & $-0,11501$ & $-0,22332$ & $-0,03392$ & $-0,15742$ \\
SMGR & $-0,31563$ & $-0,45236$ & $-0,16895$ & $-0,05796$ & $-0,16171$ \\
TLKM & $-0,32086$ & $-0,21026$ & $-0,18337$ & $-0,30163$ & $-0,39678$ \\
UNTR & $-0,31970$ & $-0,11374$ & $-0,00742$ & $-0,23330$ & $-0,29160$ \\
UNVR & $-0,41668$ & $-0,22105$ & $-0,09995$ & $-0,38062$ & $-0,30395$ \\
\hline \multicolumn{5}{l}{ Sumber: Data diolah, 2020 }
\end{tabular}

Tabel 2 di atas memperlihatkan bahwa indeks Sharpe dari periode 2015 hingga 2019 berada pada kisaran minimal -0,46671 hingga kisaran maksimal sebesar 0,13541. Jika nilai indeks kinerja Sharpe positif dan semakin besar, maka kinerja portofolio semakin baik. Periode tahun 2015 hingga 2019 dari metode Sharpe sebagian besar bernilai negatif. Selama periode penelitian hanya ada beberapa emiten yang memiliki indeks Sharpe positif yaitu ADRO pada tahun 2016 dan BBNI pada tahun 2017.

\section{Analisis Kinerja Portofolio Saham dengan Metode Treynor}

Hasil perhitungan beta periode 2015 hingga 2019 berada di kisaran angka antara -0,9838 sampai dengan 3,6638. Sekuritas yang memiliki nilai beta $<1$ menunjukkan bahwa risikonya lebih kecil dari risiko portofolio pasar. Di sisi lain sekuritas yang mempunyai nilai beta $>1$ menunjukkan bahwa risiko sistematiknya lebih besar dari risiko pasar. Return dianggap sebagai ukuran terbaik dalam memprediksi ketika pasar diasumsikan efisien. Perbandingan nilai return dan risiko investasi menunjukkan bahwa semakin tinggi risiko, maka semakin tinggi pula return yang diharapkan. Hasil perhitungan kinerja portofolio saham dari 14 emiten di IDX30 dengan metode Treynor dapat dilihat dalam tabel 3 di bawah ini.

Tabel 3. Kinerja Portofolio Metode Treynor

\begin{tabular}{llllll}
\hline Emiten & $\mathbf{2 0 1 5}$ & $\mathbf{2 0 1 6}$ & $\mathbf{2 0 1 7}$ & $\mathbf{2 0 1 8}$ & $\mathbf{2 0 1 9}$ \\
\hline ADRO & $-0,15$ & 0,03 & $-0,03$ & $-0,05$ & $-0,01$ \\
ASII & $-0,05$ & $-0,02$ & $-0,03$ & $-0,04$ & $-0,06$ \\
BBCA & $-0,10$ & $-0,03$ & 0,00 & $-0,12$ & $-0,11$ \\
BBNI & $-0,04$ & $-0,03$ & 0,00 & $-0,03$ & $-0,04$ \\
GGRM & $-0,14$ & $-0,18$ & $-0,02$ & $-0,04$ & $-0,06$ \\
INDF & $-0,11$ & $-0,01$ & $-0,04$ & $-0,04$ & $-0,10$ \\
INTP & $-0,05$ & $-0,09$ & 0,00 & $-0,02$ & $-0,06$ \\
KLBF & $-0,12$ & $-0,02$ & $-0,04$ & $-0,05$ & $-0,04$ \\
LPPF & $-0,05$ & $-0,03$ & 0,08 & $-0,07$ & $-0,02$ \\
PGAS & $-0,06$ & $-0,04$ & $-0,09$ & $-0,01$ & $-0,02$ \\
SMGR & $-0,07$ & $-0,06$ & $-0,03$ & $-0,01$ & $-0,02$ \\
TLKM & $-0,08$ & $-0,04$ & $-0,04$ & 0,11 & $-0,10$
\end{tabular}




\begin{tabular}{llllll} 
UNTR & $-0,10$ & $-0,03$ & 0,00 & $-0,12$ & $-0,11$ \\
UNVR & $-0,46$ & $-0,04$ & $-0,01$ & $-0,11$ & $-0,07$ \\
\hline \multicolumn{5}{l}{ Sumber: Data diolah, 2020}
\end{tabular}

Berdasarkan tabel 3 di atas, tampak bahwa indeks Treynor dari periode 2015 hingga 2019 berada pada kisaran minimal -0,46366 hingga kisaran maksimal 0,10655. Jika nilai Treynor positif dan semakin besar nilainya, maka kinerja portofolio perusahaan semakin baik. Selama periode tahun 2015 hingga 2019, sebgaian besar nilai indeks Treynor saham-saham IDX30 bernilai negatif. Hanya ada empat emiten yang memiliki indeks Treynor positif, yaitu ADRO pada tahun 2016, BBNI pada tahun 2017, LPPF pada tahun 2017, dan TLKM pada tahun 2018.

\section{Analisis Kinerja Portofolio Saham dengan Metode Jensen}

Metode Jensen memperhitungkan return rata-rata masa lalu dan minimum rate of return yang dihitunng dengan Capital Asset Pricing Model (CAPM). Selisih antara average return dengan minimum rate of return yang disebut dengan istilah alpha.

Jensen Alpha merupakan ukuran absolut yang mengestimasikan tingkat pengembalian konstan selama periode investasi yang memperoleh tingkat Jensen Alpha pengembalian di atas maupun di bawah dari buy-hold strategy dengan risiko sistematik yang sama. Data yang dibutuhkan dalam menganalisis indeks Jensen adalah average of return, beta saham, minimum rate, dan risk free rate. Hasil perhitungan kinerja portofolio saham IDX30 dengan metode Jensen tercantum dalam tabel 4 di bawah ini:

Tabel 4. Kinerja Portofolio Metode Jensen

\begin{tabular}{cccccc}
\hline Emiten & $\mathbf{2 0 1 5}$ & $\mathbf{2 0 1 6}$ & $\mathbf{2 0 1 7}$ & $\mathbf{2 0 1 8}$ & $\mathbf{2 0 1 9}$ \\
\hline ADRO & 0,67 & 2,05 & 1,41 & 1,66 & 2,37 \\
ASII & 1,61 & 1,97 & 1,31 & 1,34 & 1,17 \\
BBCA & 0,65 & 1,08 & 0,73 & 0,53 & 0,65 \\
BBNI & 1,82 & 1,76 & 2,00 & 2,05 & 1,56 \\
GGRM & 0,43 & 0,22 & 1,08 & 1,41 & 1,53 \\
INDF & 0,75 & 1,70 & 1,06 & 1,20 & 0,45 \\
INTP & 1,32 & 0,91 & 3,76 & 2,79 & 0,81 \\
KLBF & 0,70 & 2,00 & 0,81 & 1,21 & 1,16 \\
LPPF & 1,15 & 2,58 & $-1,09$ & 1,20 & 2,80 \\
PGAS & 1,71 & 1,36 & 0,77 & 3,06 & 2,58 \\
SMGR & 1,11 & 1,24 & 1,08 & 3,48 & 2,33 \\
TLKM & 0,73 & 1,07 & 0,96 & $-0,69$ & 0,50 \\
UNTR & 0,65 & 1,08 & 0,73 & 0,53 & 0,65 \\
UNVR & 0,07 & 1,46 & 1,52 & 0,56 & 0,87 \\
\hline Sumber: Data diolah, 2020 &
\end{tabular}


Analisis Perbandingan Kinerja Portofolio Saham dengan Metode Sharpe, Treynor, dan Jensen

Kinerja portofolio dalam penelitian ini diukur menggunakan metode Sharpe, Treynor, dan Jensen yang memiliki formulasi dan karakteristik pengukuran kinerja berbeda sehingga hasil perhitungan angka indeksnya juga berbeda. Setelah diperoleh peringkat kinerja portofolio dari masing-masing emiten, langkah selanjutnya adalah menguji apakah kinerja portofolio pada setiap periode akan memiliki peringkat yang sama jika diukur menggunakan metode Sharpe, Treynor, dan Jensen yang memiliki karakteristik berbeda. Setiap sampel diukur dengan semua kondisi yaitu diukur menggunakan metode Sharpe, Treynor, dan Jensen yang ditransformasi kedalam Z-score kemudian dibuat pemeringkatan menggunakan one way analysis of variance by rank dengan uji Kruskal Wallis.

Uji Kruskal Wallis adalah uji non parametrik berbasis peringkat yang tujuannya untuk menentukan apakah ada perbedaan signifikan secara statistik antara dua atau lebih kelompok variabel independen pada variabel dependen yang berskala data numerik (interval/rasio) dan skala ordinal (statistikian.com: 2014). Variabel dependen dalam penelitian ini adalah peringkat yang berupa rasio 1-3 dan variabel independen berupa metode dengan 3 kategori yaitu Sharpe, Treynor, dan Jensen.

Tabel 5. NPar Tests

\begin{tabular}{llllll}
\hline & N & Mean & Std. Deviation & Minimum & Maximum \\
\hline Zscore & 210 & 0,0000003 & 0,99520374 & $-2,77332$ & 3,15072 \\
Metode & 210 & 2,00 & 0,818 & 1 & 3 \\
\hline
\end{tabular}

Sumber: Output SPSS 25, 2020

Tabel 5 di atas menunjukkan jumlah seluruh sampel dalam penelitian ini yaitu sebanyak 210 dengan nilai mean -,0000003 dan standar deviasi sebesar 0,99520374. Nilai minimum yang dihasilkan yaitu sebesar $-2,77332$ yang dihasilkan dari pengukuran indeks Sharpe dan nilai maksimum sebesar 3,15072 yang diperoleh dari pengukuran indeks Jensen. Hasil uji menggunakan Kruskal Wallis dapat dilihat pada tabel IV-8 berikut.

Tabel 6. Hasil Uji Kruskal Wallis

\begin{tabular}{ll}
\hline & Zscore \\
\hline Kruskal-Wallis H & 0,598 \\
Df & 2 \\
Asymp. Sig. & 0,742 \\
\hline Sumber: Output SPSS 25, 2020
\end{tabular}

Sumber: Output SPSS 25, 2020

Berdasarkan hasil pengujian dengan uji Kruskal Wallis pada ketiga metode, diperoleh $x^{2}=0,598$ dengan probabilitas 0,742 . Diketahui bahwa probabilitas pengujian $\geq 0,05$ dan $x^{2}$ hitung $<$ tabel Chi-Square $(5,99)$. Hasil ini menunjukkan bahwa tidak ada perbedaan yang signifikan antara pengujian dengan metode Sharpe, Treynor, dan Jensen, artinya hipotesis nihil $\left(\mathrm{H}_{0}\right)$ dalam penelitian ini diterima.

Tidak adanya perbedaan antara ketiga metode tersebut dalam mengukur kinerja portofolio menunjukkan bahwa pengukuran menggunakan metode Sharpe, Treynor, dan Jensen tidak menghasilkan perbedaan yang signifikan terhadap hasil kerja portofolio dalam suatu 
periode.Pengujian selanjutnya adalah dengan membanding-kan mean antar treatment perhitungan kinerja portofolio untuk mengetahui selisih ketiga mean rank. Perbandingan antar treatment untuk masing-masing metode dapat dilihat dalam tabel 7 di bawah ini:

Tabel 7. Perbandingan antar Treatment

\begin{tabular}{llll}
\hline & Metode & $\mathrm{N}$ & Mean Rank \\
\hline Zscore & Sharpe & 70 & 104,73 \\
& Treynor & 70 & 109,80 \\
& Jensen & 70 & 101,97 \\
& Total & 210 & \\
\hline
\end{tabular}

Sumber: Output SPSS 25, 2020

Berdasarkan selisih ketiga mean rank, maka metode Sharpe adalah yang paling menunjukkan konsistensi terhadap ketidakbedaan antara ketiga metode pengukuran, karena nilai Sharpe memiliki selisih yang paling rendah terhadap Treynor maupun Jensen. Selisih antar mean rank ini menunjukkan tidak ada yang melebihi nilai kritis yaitu sebesar 30,124, artinya 3 metode pengukuran yang digunakan dalam mengukur kinerja portofolio relatif konsisten untuk mengukur kinerja portofolio saham.

Tabel 4 di atas menunjukkan bahwa indeks Jensen dari periode 2015 hingga 2019 berada pada kisaran minimal -1,08733 hingga kisaran maksimal 3,76403. Nilai Jensen Alpha yang tertinggi dan signifikan merupakan portofolio yang terbaik. Jika nilai alpha positif menunjukkan bahwa kinerja yang portofolio yang dihasilkan lebih baik daripada indeks pasar, sebaliknya jika nilai alpha negatif maka kinerja portofolionya lebih rendah daripada indeks pasar.

Pada periode 2015 hingga 2019 hasil perhitungan dari indeks Jensen saham IDX30 sebagian besar bernilai positif. Ada dua perusahaan yang mengalami indeks Jensen negatif selama periode 2015 hingga 2019, yaitu LPPF pada tahun 2017 dan TLKM pada tahun 2018.

\section{Analisis Saham-Saham IDX30 yang Layak untuk Diinvestasikan}

Pada tahun 2015 saham BBNI memperoleh peringkat tertinggi, yakni sebesar 0,63996 berdasarkan skor Z Jensen. Hal ini menunjukkan bahwa BBNI pada tahun 2015 mampu memberikan return yang tinggi dalam menanggung risiko sistematisnya dan return yang lebih besar daripada return harapannya.

Pada tahun 2016, ADRO memperoleh peringkat tertinggi yaitu sebesar 2,93414 berdasarkan skor Z Sharpe. Hal ini menunjukkan bahwa ADRO pada tahun 2016 mampu memberikan return yang tinggi dalam menanggung risiko total (risiko sistematis dan tidak sistematis).

Pada tahun pada tahun 2017 INTP memperoleh peringkat tertinggi sebesar 2,93976 berdasarkan skor Z Jensen. Hal ini menunjukkan bahwa INTP pada tahun 2017 mampu memberikan return yang tinggi dalam menanggung risiko sistematisnya dan return yang lebih besar dari return yang diharapkan.

Pada tahun 2018 SMGR memperoleh peringkat tertinggi sebesar 2,60099 berdasarkan skor Jensen. Hal ini menunjukkan bahwa pada tahun 2018 SMGR mampu memberikan return yang tinggi dalam menanggung risiko sistematisnya dan return yang lebih besar dari return yang diharapkan. 
Pada tahun 2019 LPPF memperoleh peringkat tertinggi sebesar 1,79882 dari skor Z Jensen. Hal ini menunjukkan bahwa pada tahun 2019 SMGR mampu memberikan return yang tinggi dalam menanggung risiko sistematisnya dan return yang lebih besar dari return yang diharapkan.

Jika merujuk pada nilai Zscore Sharpe, Treynor, dan Jensen portofolio IDX30 selama periode 2015 hingga 2019 ada beberapa saham yang layak dipilih untuk dijadikan pilihan investasi, yaitu: BBNI, ADRO, INTP, SMGR, dan LPPF. Jika merujuk pada nilai masing-masing indeks pada periode 2015 hingga 2019, maka saham yang layak dipilih antara lain: ADRO dari indeks Sharpe pada tahun 2015, TLKM dari indeks Treynor pada tahun 2018, serta INTP dari indeks Jensen pada tahun 2017.

Risiko investasi yang tinggi belum tentu memberikan return yang tinggi (high risk-high return). Hal ini terlihat dari perhitungan nilai risiko sistematis yang disimbolkan dengan beta, risiko total yang disimbolkan dengan deviasi standar, serta nilai return portofolio selama periode 2015 hingga 2019 pada portofolio IDX30 yang disimbolkan dengan $R p$. Untuk mempermudah pembaca dalam memahami hasil perhitungan dapat dilihat dalam tabel 8 berikut ini.

Tabel 8. Perbandingan Peringkat Portofolio IDX30

\begin{tabular}{llcllclll}
\hline Emiten & $\boldsymbol{R} \boldsymbol{p}$ & Peringkat & Emiten & $\boldsymbol{\beta}$ & Peringkat & Emiten & $\boldsymbol{\sigma}$ & Peringkat \\
\hline BBCA & $1,66 \%$ & 1 & INTP & $193 \%$ & 1 & LPPF & $29 \%$ & 1 \\
ADRO & $1,36 \%$ & 2 & PGAS & $191 \%$ & 2 & INTP & $28 \%$ & 2 \\
BBNI & $0,75 \%$ & 3 & BBNI & $185 \%$ & 3 & KLBF & $28 \%$ & 3 \\
TLKM & $0,72 \%$ & 4 & SMGR & $185 \%$ & 4 & INDF & $28 \%$ & 4 \\
UNTR & $0,62 \%$ & 5 & ADRO & $174 \%$ & 5 & BBNI & $27 \%$ & 5 \\
UNVR & $0,43 \%$ & 6 & ASII & $146 \%$ & 6 & GGRM & $27 \%$ & 6 \\
INDF & $0,32 \%$ & 7 & LPPF & $136 \%$ & 7 & PGAS & $27 \%$ & 7 \\
INTP & $0,17 \%$ & 8 & KLBF & $120 \%$ & 8 & ADRO & $26 \%$ & 8 \\
GGRM & $0,11 \%$ & 9 & BBCA & $114 \%$ & 9 & BBCA & $26 \%$ & 9 \\
SMGR & $0,09 \%$ & 10 & INDF & $106 \%$ & 10 & ASII & $26 \%$ & 10 \\
ASII & $0,01 \%$ & 11 & GGRM & $96 \%$ & 11 & SMGR & $23 \%$ & 11 \\
KLBF & $-0,05 \%$ & 12 & UNVR & $91 \%$ & 12 & UNTR & $22 \%$ & 12 \\
PGAS & $-0,61 \%$ & 13 & UNTR & $77 \%$ & 13 & TLKM & $21 \%$ & 13 \\
LPPF & $-1,51 \%$ & 14 & TLKM & $56 \%$ & 14 & UNVR & $19 \%$ & 14 \\
\hline Sum & & & & & & & &
\end{tabular}

Sumber: Data diolah, 2020

Berdasarkan tabel 8 di atas, peringkat return tertinggi diperoleh BBCA dan peringkat terendah diperoleh LPPF. Jika investor mengharapkan return yang tinggi berdasarkan data return historis tahun 2015-2019, maka saham BBCA layak untuk dibeli karena rata-rata return-nya paling tinggi. Langkah selanjutnya dalam analisis kinerja portofolio adalah memperhatikan risiko sistematis yang disimbolkan dengan beta $(\beta)$. Beta menunjukkan besarnya risiko yang dihadapi emiten karena faktor fluktuasi pasar.

Berdasarkan tabel 8, INTP menunjukkan kinerja yang paling baik dalam menanggung risiko sistematis, sementara TLKM menunjukkan kinerja yang paling rendah dalam menanggung risiko sistematis. Tinggi rendahnya nilai beta saham menunjukkan seberapa besar dampak fluktuasi pasar terhadap emiten yang bersangkutan. Semakin besar nilai beta sahamnya, maka semakin kecil dampak fluktuasi pasar terhadap perusahaan sekaligus memberikan jaminan imbal hasil investasi yang tinggi. 
Terkait kemampuan perusahaan dalam menanggung risiko total (risiko sistematis dan risiko tidak sistematis) disimbolkan dengan deviasi standar. Berdasarkan tabel IV-10, LPPF menduduki peringkat pertama sebagai emiten yang paling mampu menanggung risiko total. Di sisi lain UNVR memperoleh nilai deviasi standar dengan peringkat terkecil. Hal ini menunjukkan kemampuan UNVR dalam menanggung risiko total belum cukup bagus.

Hasil dari perhitungan return portofolio, beta, dan deviasi standar dari tabel 8 membuktikan bahwa nilai return yang tinggi menunjukkan kemampuan dalam menanggung risiko sistematis dan risiko total yang sepadan. Peringkat LPPF sebagai emiten yang memberikan return terendah sebesar $-1,51 \%$, dengan kemampuan menanggung risiko sistematis yang sedang di peringkat 7 sebesar $136 \%$, dan kemampuan menanggung risiko total sebagai peringkat 1 sebesar 29\%. Hal ini menunjukkan bahwa return yang rendah memiliki kemampuan menanggung risiko yang cukup baik. Hal ini membuktikan bahwa teori high riskhigh return berlaku yang mana pada kasus LPPF adalah low risk-low return.

Pada hasil analisis return rata-rata BBCA yang memperoleh peringkat pertama sebesar 1,66\%, ternyata memiliki kemampuan dalam menanggung risiko total di peringkat ke-9 sebesar $26 \%$ dan kemampuan menanggung risiko sistematis di peringkat 9 sebesar $114 \%$. Hal ini menunjukkan bahwa BBCA memiliki return yang tinggi dengan tingkat risiko yang sedang.

\section{Simpulan}

Kinerja portofolio menggunakan metode Sharpe, Treynor, dan Jensen menunjukkan kinerja yang merata nilainya. Ada beberapa emiten yang kinerjanya bagus seperti selama periode penelitian yaitu ADRO pada tahun 2016 dan BBNI pada tahun 2017 dari hasil indeks Sharpe . Emiten yang memiliki indeks Treynor positif, yaitu ADRO pada tahun 2016, BBNI pada tahun 2017, LPPF pada tahun 2017, dan TLKM pada tahun 2018. Hasil pengukuran menggunakan indeks Jensen menunjukkan sebagian besar emiten memiliki kinerja yang bagus karena nilainya positif, namun ada dua emiten yang hasil indeksnya bernilai negatif yaitu LPPF pada tahun 2017 dan TLKM pada tahun 2018.

Hasil uji beda pengukuran kinerja portofolio menggunakan metode Sharpe, Treynor, dan Jensen dengan uji Kruskal Wallis tidak menunjukkan ada perbedaan yang signifikan dalam mengukur kinerja portofolio. Uji antar treatment juga tidak menunjukkan adanya perbedaan secara signifikan antara metode Sharpe, Treynor, dan Jensen dalam mengukur kinerja portofolio IDX30.

Pengukuran menggunakan selisih mean rank menunjukkan metode Sharpe sebagai metode yang paling konsisten dibanding metode Treynor dan Jensen. Hal ini karena Sharpe memiliki selisih mean rank yang paling rendah terhadap Treynor maupun Jensen yang mana selisihnya tidak melebihi nilai kritis 30,124.

Hasil penelitian ini membuktikan bahwa tidak ada perbedaan yang signifikan antara metode Sharpe, Treynor, dan Jensen sehingga dapat digunakan secara bersama-sama dalam mengontrol kinerja portofolio saham bagi pihak yang bersangkutan. Hasil penelitian ini sejalan dengan penelitian sebelumnya yang dilakukan oleh Agus Sulistyorini (2009), Suryania, Arna \& Eva 
Herianti (2015), Esa Fitriani Komara (2015), Bukit, P, Darmayanti, Ni Putu Ayu, dkk (2018), serta Yunan Surono, \& Nani Astriana (2019), yang menunjukkan tidak ada perbedaan yang signifikan antara metode Sharpe, Treynor, dan Jensen.

Hasil penelitian ini tidak sejalan dengan temuan Citrayani Tuerah (2013) yang menggunakan uji beda sampel dan ANOVA dengan hasil penelitian berbeda signifikan antara actual return dengan excess return. Dalam penelitian ini, penulis tidak menggunakan uji ANOVA karena setelah dicoba, ternyata distribusi datanya tidak normal sehingga membutuhkan alat uji lain (dalam hal ini menggunakan statistik non-parametrik uji Kruskal Wallis.

Hasil penelitian ini menunjukkan perbedaan dalam penentuan metode yang paling konsisten, metode Sharpe yang paling konsisten, namun dalam penelitian Sulistyorini (2009) menunjukkan bahwa metode Treynor yang paling konsisten, sementara dalam penelitian Bukit, Pantul dkk metode yang paling konsisten adalah metode Jensen.

Keterbatasan dalam penelitian ini adalah pengukuran kinerja portofolio hanya menggunakan metode Sharpe, Treynor, dan Jensen. Penggunaan metode Sharpe, Treynor, dan Jensen dalam evaluasi kinerja portofolio optimal dapat dilengkapi dengan metode pengukuran lain seperti reward to market risk, reward to diversification, $M^{2}$, Sortino, dan ratio information. Kinerja portofolio optimal dalam penelitian ini menghitung return dari sisi closing price emiten saja, tidak memperhitungkan dividen yang dibagikan. Jika dividen ikut dimasukkan dalam perhitungan, maka return yang mencakup rata-rata harga saham di masa lalu dan pembagian dividen di masa lalu akan lebih meyakinkan calon investor untuk berinvestasi.

\section{Referensi}

Bloomberg. (2020). CPIDX30:IJ Principal Index IDX30. Available at: https://www.bloomberg.com/quote/ CPIDX30:IJ/ 7 Maret 2020.

Bursa Efek Indonesia. (2020). IDX Stock Index Handbook v1.1. Available at: https://www.idx.co.id/media/8572/idx-stock-index-handbook-_-v11-_-desember2019.pdf/ 14 Juni 2020.

Darmayanti, N. P. A., Suryantini, N. P. S., Rahyuda, H., \& Dewi, S. K. S. (2018). Perbandingan Kinerja Reksa Dana Saham dengan Metode Sharpe, Treynor, dan Jensen. Jurnal Riset Ekonomi dan Bisnis, 11(2), 93-107.

Halim, A. (2015). Analisis Investasi dan Aplikasinya dalam Aset Keuangan dan Aset Riil. Jakarta: Salemba Empat.

Hartono, J. (2010). Teori Portofolio dan Analisis Investasi. Yogyakarta: BPFE.

Hartono, J.. (2013). Teori Portofolio dan Analisis Investasi. Yogyakarta: BPFE-UGM.

Hartono, J.. (2017). Teori Portofolio dan Analisis Investasi. Edisi Kesebelas. Yogyakarta: BPFE..

Hidayat, A. (2014). Penjelasan dan Teori Uji Kruskal Wallis H. Available at: https://www.statistikian.com/2014/07/uji-kruskall-wallis-h/ 4 Agustus 2020. 
Komara, E. F. (2015). Perbandingan Kinerja Portofolio Saham dengan Metode Sharpe, Treynor, dan Jensen (Kajian Empiris Berdasarkan Indeks LQ-45 dan Jakarta Islamic Indeks). Prosiding. Disajikan dalam Seminar Nasional Ekonomi dan Bisnis, UNJANI, 43-49.

Maf'ula, Z., Rahayu, S. R., \& Zahroh ZA, Z. Z. (2018). Portofolio Optimal Dengan Penerapan Model Markowitz Sebagai Dasar Keputusan Investasi (Studi Pada Perusahaan yang Tergabung Dalam Indeks LQ-45 Tahun 2014). Jurnal Administrasi Bisnis, 63(1), 17-23.

Manurung, A. H. (2002). “Mengukur Kinerja Portofolio”, Usahawan, 11, 41-46.

Manurung, H. (2019). Analisis Kinerja Portofolio Saham dengan Menggunakan Metode Sharpe, Jensen dan Treyno. Journal of Business Studies, 4(1), 1-16.

Samsul, M. (2006). Pasar Modal dan Manajemen Portofolio. Jakarta: Erlangga.

Samsul, M. (2015). Pasar Modal dan Manajemen Portofolio. Jakarta: Erlangga.

Sulistyorini, A. (2009). Analisis Kinerja Portofolio Saham Dengan Metode Sharpe, Treynor dan Jensen (Saham LQ45 di Bursa Efek Indonesia Tahun 2003 Sampai 2007). Jurnal Fakultas Ekonomika dan Bisnis Universitas Diponegoro.

Supranto, J. (2009). Statistik: Teori dan Aplikasi. Edisi Ketujuh. Jakarta: Erlangga.

Suryani, A., \& Herianti, E. (2015). The analysis of risk adjusted return portfolio performance share for LQ 45 index in indonesia stock exchange in 2010-2014 periods. Procedia-Social and Behavioral Sciences, 211, 634-643.

Tandelilin, E. (2010). Portofolio dan Investasi Teori dan Aplikasi. Edisi Pertama. Yogyakarta: Kanisius.

Tuerah, C. (2013). Perbandingan Kinerja Saham LQ 45 Tahun 2012 Menggunakan Metode Jensen, Sharpe Dan Treynor. Jurnal EMBA: Jurnal Riset Ekonomi, Manajemen, Bisnis dan Akuntansi, 1(4).

Wiyono, G., \& Kusuma, H. (2017). Manajemen Keuangan Lanjutan (Berbasis Corporate Value Creation). Yogyakarta: UPP STIM YKPN. 